\title{
Species Composition, Relative Abundance and Distribution of Rodents in Wof-Washa Natural State Forest, North Shewa, Amhara, Ethiopia
}

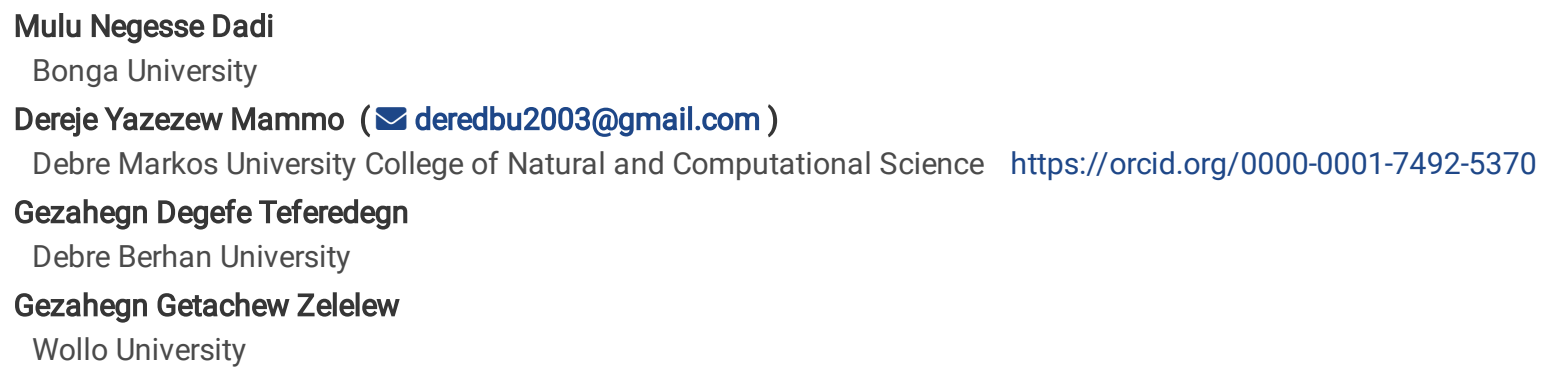




\section{Abstract}

Background: The species composition, relative abundance and distribution of rodents were studied in Wof-Washa Natural State Forest, Ethiopia from December 2016 to May 2017 during dry and wet seasons. A total of 49 Sherman live traps were set per grid at $10 \mathrm{~m}$ intervals in permanent $4900 \mathrm{~m}^{2}(70 \mathrm{~m} \times 70 \mathrm{~m})$ live trapping grids established in intact forest, disturbed forest, Erica woodland, plantation forest and Farmland habitats.

Result: A total of 621 individuals of rodents were captured in 2,560 trap nights by using both live traps and snap traps. Seven species of rodents in family Muridae were recorded. Out of the total rodents caught in the study period, Stenocephalemys albipes, Pelomys harringtoni and Lophuromys flavopunctatus are endemics to Ethiopia. Plantation forest had the highest mean trapping success whereas the lowest trap success was in the Erica woodland. The distribution of rodent species was significantly differed $(\mathrm{P}<0.05)$ among studied habitats. Higher trap success was recorded in dry season (26.2) than the wet season (24.4). The highest value of Shannon index was recorded in plantation forest $\left(H^{\prime}=1.82\right)$ followed by farmland habitat $\left(H^{\prime}=1.67\right)$ during the wet season and the lowest value was observed in the intact forest $\left(H^{\prime}=0.67\right)$ and Erica woodland $\left(H^{\prime}=0.67\right)$ during the dry season. From the total catch, adults comprised $260(41.9 \%)$, sub-adults $248(39.9 \%)$ and juveniles 113(18.2\%).

Conclusion: The present study provides the first valuable demonstration on the species composition, relative abundance and distribution of rodents in the WWNSF. Further monitoring and inventory of small mammals is warranted to document and conserve the different endemic and endangered rodent species to designing important biodiversity management plan in the area.

\section{Introduction}

Ethiopia is endowed with extensive and unique environmental conditions, ranging from $100 \mathrm{~m}$ below sea level at Kobar in Afar depression to the summits reach heights of up to $4620 \mathrm{~m}$ Ras Dejen [1, 2]. These endowments of topographical and environmental variability are sources of endemism in both fauna and flora of the country [3]. Many of these endemic faunal species are specifically associated with the high-altitude moorland and grassland habitats [1].

Rodents are vital components of food web in the ecosystem that provide the main supply of fresh food for many predators [4, 5], important sources of food or fur for humans [6, 7], serve as biological control agents [8], social and cultural values [9] and educational and research model $[7,10]$. Rodents are the most successful mammals adapted to wide range of environments in the world and show great diversity in their ecology, morphology, physiology, behavior and life history strategies [11]. The distribution and abundance of rodents are influenced by availability of food sources and shelter, habitat heterogeneity and stability, seasonal variation of climatic conditions, predator status, and other ecological requirements like the nature and density of vegetation in their habitat [12-16].

Globally, rodents comprise $42 \%$ among mammalian orders and represent the largest order with Over 32 extant families, 468 genera and 2,277 species $[17,18]$. There are about 14 families, 89 genera and 290 species of rodents in Africa which are most ubiquitous and abundant than other mammalian order [19]. Ethiopia possesses 84 species of rodents of which 36 are endemic that comprise $65.5 \%$ of the total endemic mammal species of the country $[13,20]$. Faunal exploration is an important component of future conservation endeavor and helps in understanding the potential of the area in composition and diversity of animals [21]. Information regarding faunal diversity reinforces scientific knowledge and boosts the importance of an area to establish protected areas and refugia [7]. Although Ethiopia is endowed with high rodent diversity and endemism [7, 15, 22], no studies have been carried out on population and behavioral ecology of rodents in WWNSF due to inaccessibility, inhospitable conditions and remoteness of the area. Accordingly, the present study is crucial to document ecological information on species composition, relative abundance and distribution of rodents in WWNSF.

\section{Materials And Methods}

\section{Study area}

The study on the species composition, relative abundance and distribution of rodents was conducted in Wof-Washa Natural State Forest (WWNSF), which is located in North Shewa Zonal administration, Amhara Region, Northwestern highlands of Ethiopia. The escarpment forms part of the catchment of the Awash River system which drains into the Danakil Plains in the northern section of the Rift Valley [23]. It extends approximately between $9^{\circ} 42^{\prime}-9^{\circ} 47^{\prime} \mathrm{N}$ latitude and between $39^{\circ} 43^{\prime}-39^{\circ} 49^{\prime} \mathrm{E}$ longitude (Fig. 1). The area encompasses an altitudinal range between 1650 to $3600 \mathrm{~m}$ asl. WWNSF is one of the very few remaining Dry Afro-montane forests and the oldest natural state forest in Ethiopia. The mean annual temperature of the study area is $13.13^{\circ} \mathrm{C}$ ranging from the mean annual minimum temperature of $6.3^{\circ} \mathrm{C}$ to the mean annual maximum temperature of $20^{\circ} \mathrm{C}$. The rainfall distribution in the area is bimodal with the mean annual rainfall of the study area is $1840 \mathrm{~mm}[24]$. The vegetation of WWNSF can best be described as dry evergreen afromontane forest mixed with both broadleaved and conifers in the eastern escarpment of the Northwestern highlands with clear Ericaceous belt at the higher altitude [24]. Generally, there are over 394 species of plants, of which, 46 species (12\%) are endemic to Ethiopia while $7(2 \%)$ are nearly endemic $[25,26]$. In spite of the forest's biodiversity, economic, and 
ecological significance for the districts harboring it, no action has been taken to preserve the forest and its surrounding villages until recently and the forest is under threat of reduction in size and density accordingly.

\section{Methods}

Preliminary survey was conducted from September to November 2016 to gather relevant information regarding climatic conditions, vegetation and habitat types and topography. Based on the topography and vegetation structure, the study area was classified into intact forest (IF), disturbed forest (DF), Erica woodland (EWL), Plantation Forest (PF) and farmland (FL). Representative grids were selected from these different habitat types in the study area (Table 1). The area of each grid was $4900 \mathrm{~m}^{2}$ and coded sequentially. Both live-traps and snap-traps were used for data collection and trapping sites were located $>200 \mathrm{~m}$ apart each other.

Table 1. Description of habitat types of sampling sites

\begin{tabular}{|c|c|}
\hline $\begin{array}{l}\text { Habitat } \\
\text { Type }\end{array}$ & Description \\
\hline $\begin{array}{l}\text { Intact } \\
\text { Forest }\end{array}$ & $\begin{array}{l}\text { A naturally regenerated forest of native species, where there are no clearly visible indications of human activities and the } \\
\text { ecological processes are not significantly disturbed. This Forest type is largely the product of natural and ongoing evolutionary, } \\
\text { ecological and biological processes with minimal disturbance events. It is located within altitudinal ranges of } 2685-2721 \mathrm{~m} \text { asl } \\
\text { (Fig. } 2 \text { A) and dominated by tree species such as Juniperus procera, Olea europaea spp. Cuspidiata, Podocarpus falcatus, } \\
\text { Maytenus, arbutifolia, Erica arborea, Ilex mites, Myrsine africana and Galineira saxifraga which accounted } 65 \% \text { of the total } \\
\text { density in the forest [27]. }\end{array}$ \\
\hline $\begin{array}{l}\text { Disturbed } \\
\text { Forest }\end{array}$ & $\begin{array}{l}\text { Forest type with native or introduced tree species that spread and multiply by natural regeneration but vegetation structure } \\
\text { cannot reflect natural optima due to changes in the structure and composition of a forest ecosystem and maintained in a } \\
\text { degraded state due to human disturbance (Fig. 2B). The altitudinal range of grid selected in this habitat is } 2706 \text { to } 2733 \mathrm{~m} \text { asl. }\end{array}$ \\
\hline $\begin{array}{l}\text { Erica } \\
\text { bushland }\end{array}$ & $\begin{array}{l}\text { This habitat type is located in the highest peak of the forest dominated by Erica scrubs (Fig. 2C) and with altitudinal ranges of } \\
3182 \text { to } 3232 \mathrm{~m} \text { asl. }\end{array}$ \\
\hline $\begin{array}{l}\text { Plantation } \\
\text { Forest }\end{array}$ & $\begin{array}{l}\text { A forest established by planting or/and seeding in the process of afforestation or reforestation and consists of two or more } \\
\text { introduced or indigenous species of trees and grasses with successful co-existence in monodominant forest (Fig. 2D). The grid } \\
\text { selected in this habitat ranges } 2702 \text { to } 2735 \mathrm{~m} \text { asl. }\end{array}$ \\
\hline Farmland & $\begin{array}{l}\text { This habitat is dominated by cultivated crop species with few scattered remnants tress species indicating that the area is } \\
\text { previously covered by forest (Fig. 2E). The grids were selected in the altitude ranging from } 2900 \text { to } 2970 \mathrm{~m} \text {. asl. }\end{array}$ \\
\hline
\end{tabular}

\section{Trapping}

Data were collected during both the dry season (December 2016 and February 2017) and wet season (April and May 2017). Permanent $4900 \mathrm{~m}^{2}$ live trapping grids were established at five randomly selected sites to represent each habitat type [11]. A standard square (seven rows by seven columns) trapping grid was established in each trapping site, during dry and wet seasons [28]. Accordingly, a total of 49 Sherman live traps were set per grid at $10 \mathrm{~m}$ intervals $(70 \mathrm{~m} \times 70 \mathrm{~m})[12,21,29,30]$ (Fig. 3). Traps were baited with peanut butter and covered with grass and tree leaves to discourage disturbances by local people. Traps were checked twice a day at early morning (between 07:00 and 09:00) and late afternoon (between 16:00 and 18:00). Trapping was conducted for three consecutive days in each habitat during each of the trapping sessions. GPS points of trap locations were recorded by their code number for check over. Each trapped rodents were removed from the traps and placed inside a transparent polythene bag, weighed and identified to the species level based on the weight and pelage colour. Moreover, sex, weight and approximate age (Adult, subadult and juvenile) of rodents were also determined [31]. Skin specimens of snap trapped rodents were prepared for further identification and comparison with the specimens available in the Zoological Natural History Museum of Addis Ababa University. Head to body length, tail length, ear length and hind foot

length were recorded for identification purpose. Data were analyzed using SPSS computer software programme version 20 and appropriate statistical methods. Chi-square test was used to compute species abundance, distribution, relative abundance and habitat association of rodents. Shannon-Weiner Index was used to compute rodent species diversity among the different habitat types. Habitat similarity was computed by using Simpson's Similarity index. Trapping success was calculated as

$$
\mathrm{T}=\left(\frac{\mathrm{Nm}}{\mathrm{Ntn}}\right) \times 100
$$

where $N m$ = is the set of individuals trapped, $N t n=$ the number of trap night.

\section{Results}

\section{Species composition and abundance}


A total of 621 individuals of rodents belonging to seven species under family Muridae were captured in 2,560 trap nights by using both live traps and snap traps in all five habitats

types during both wet and dry seasons (Table 1). Out of the total captured rodents, 530 (85.3\%) individuals were captured by Sherman live-traps in 1960 trap nights while 91 individual rodents were trapped using snap-traps in 600 trap nights. The species of rodents caught, identified and recorded in the study area during the trapping sessions were white-tailed Rat (Stenocephalemys albicuadata, Frick, 1914) 179(28.82\%), Ethiopian white-footed mouse (Stenocephalemys albipes, Rüppell, 1842) 174(28.02\%), broad beaked dolphins (Pelomys harringtoni, Thomas, 1903) 99(15.94\%), yellow- spotted harsh/brush-furred rat (Lophuromys flavopunctatus, Thomas, 1888) 77(12.4\%), typical veli rat (Otomys typus, Heuglin, 1877) 54(8.7\%), Natal multimammate mouse (Mastomys natalensis, Smith, 1834) 20(3.22\%) and gray-tailed narrow-headed rat (Stenocephalemys griseicauda, Petter, 1972) 18(2.9\%) (Table 1). S. albicuadata and S. albipes were the most abundant and widely distributed to different habitat types while S. griseicauda and Mastomys natalensis were the least abundant and have limited distribution in the study area. Out of the total rodents caught in the study period, Stenocephalemys albipes, Pelomys harringtoni and Lophuromys flavopunctatus are endemic to Ethiopia. In addition to rodent species trapped during the trap sessions, other rodent species such as crested porcupine (Hystrix cristata, Linnaeus, 1758) and root rat (Tachyoryctes splendens, Rüppell, 1836) were recorded from the study area directly or through indirect evidences like quills and burrows.

Plantation forest had the highest mean trapping success in both dry and wet seasons (35.2\%) followed by the farmland habitat with a mean trapping success of $30.7 \%$. The lowest trap success was recorded in the Erica woodland in the wet season (13.7\%) with the mean trapping success of $14.6 \%$ (Table 1). There was statistical variation in the trapping success between the different habitat types during the two seasons ( $P$ $<0.05)$.

Table 1. Species composition of rodent in different habitats and seasons.

\begin{tabular}{|c|c|c|c|c|c|c|c|c|c|c|c|c|}
\hline \multirow{3}{*}{ Species } & \multicolumn{12}{|c|}{ Habitat Types } \\
\hline & \multicolumn{2}{|l|}{ IF } & \multicolumn{2}{|l|}{ DF } & \multicolumn{2}{|l|}{ EWL } & \multicolumn{2}{|l|}{ PF } & \multicolumn{2}{|l|}{$\mathrm{FL}$} & \multirow[t]{2}{*}{ Total } & \multirow[t]{2}{*}{ RA } \\
\hline & dry & wet & Dry & wet & Dry & wet & Dry & wet & Dry & wet & & \\
\hline S. albicaudata & 26 & 21 & 18 & 18 & 24 & 17 & 11 & 12 & 15 & 17 & 179 & 28.82 \\
\hline S. albipes & 40 & 28 & 34 & 18 & 16 & 18 & 8 & 12 & - & - & 174 & 28.02 \\
\hline P. harringtoni & 0 & 0 & 5 & 1 & 0 & 0 & 25 & 24 & 26 & 18 & 99 & 15.94 \\
\hline L. flavopunctatus & 0 & 0 & 0 & 0 & 0 & 0 & 21 & 15 & 22 & 19 & 77 & 12.40 \\
\hline O. typus & 0 & 0 & 0 & 0 & 0 & 0 & 14 & 18 & 13 & 9 & 54 & 8.70 \\
\hline M. natalensis & 0 & 0 & 0 & 0 & 0 & 0 & 5 & 6 & 4 & 5 & 20 & 3.22 \\
\hline S. griseicauda & 0 & 0 & 0 & 0 & 0 & 0 & 5 & 4 & 3 & 6 & 18 & 2.90 \\
\hline Total No. & 66 & 49 & 57 & 37 & 40 & 35 & 89 & 91 & 83 & 74 & 621 & 100.00 \\
\hline Trap nights & 256 & 256 & 256 & 256 & 256 & 256 & 256 & 256 & 256 & 256 & 2560 & \\
\hline Trap success & 25.78 & 19.1 & 22.3 & 14.5 & 15.6 & 13.7 & 34.8 & 35.6 & 32.4 & 28.9 & 24.26 & \\
\hline
\end{tabular}

Designations: IF=Intact Forest, $\mathrm{DF}=$ Disturbed Forest, $\mathrm{EWL}=$ Erica Woodland, $\mathrm{PF}=$ Plantation Forest, $\mathrm{FL}=\mathrm{Farmland}, \mathrm{RA}=\mathrm{Re}$ lative abundance

\section{Habitat association and seasonal variation}

Most species were trapped from modified habitats (plantation and farmland habitats)

whereas least number of species were recorded from natural forest habitats. Among seven species of rodents trapped, $S$. albicaudata was found in all habitats while $S$. albipes trapped from four habitats followed by $P$. harringtoni trapped from three habitat types (Fig. 4). The total captured individuals during the wet and dry seasons were 335 (53.9\%) and 286 (46.1\%), respectively. Higher trap success was recorded in dry season (26.2) than the wet season (24.4). However, the overall abundance of rodent in dry and wet seasons was not statistically significant difference $\left(X^{2}=3.86 ; \mathrm{df}=1 ; p>0.05\right)$. Most species were trapped from plantation forest habitat

whereas the least number of species were recorded from Erica woodland and intact forest habitats (Fig. 4). Higher mean trap success of rodents was recorded in the plantation forest (35.2\%) followed by farmland habitat while the least was in Erica woodland.

\section{Altitudinal distribution of rodent species}

The abundance and diversity of species trapped at altitude 2685-2870 m asl was higher (seven species) than the higher altitude (3056-3240 m asl) (Table 2). S. albicaudata and S. albipes were abundant at the lower altitude of the trapping sites during the study period. Only these two 
species were trapped from higher altitude with relative abundance of 12.08. Moreover, higher relative abundance (63.29) of rodents was trapped in the lower altitudes of trapping sites.

\section{Species Diversity indices}

The diversity indices revealed that the plantation forest habitat has a higher species richness $(S=7)$ whereas the least number of species has been recorded in the intact forest $(S=2)$ and Erica woodland $(S=2)$. Species diversity was higher during the wet season compared to the dry season in all habitats except disturbed forest. The highest value of Shannon-Wiener index $\left(\mathrm{H}^{\prime}\right)$ was recorded in plantation forest $\left(\mathrm{H}^{\prime}=1.82\right)$ followed by farmland habitat $\left(H^{\prime}=1.67\right)$ during the wet season and the lowest value was observed in the intact forest $\left(H^{\prime}=0.67\right)$ and Erica woodland $\left(H^{\prime}=0.67\right)$ during the dry season. Higher dominance index value was observed in

Table 2. Abundance of rodent species trapped from different altitudinal zonation.

\begin{tabular}{|lllll|}
\hline \multicolumn{5}{|c}{ Altitudinal zonation (m asl) } \\
\hline Species & $2685-2870$ & $2871-3055$ & $3056-3240$ & Total \\
\hline S. albicaudata & 106 & 32 & 41 & 179 \\
\hline S. albipes & 140 & - & 34 & 174 \\
\hline P. harringtoni & 55 & 44 & - & 99 \\
\hline L. flavopunctatus & 36 & 41 & - & 77 \\
\hline O. typus & 32 & 22 & - & 54 \\
\hline M. natalensis & 15 & 5 & - & 20 \\
\hline S. griseicauda & 9 & 9 & - & 18 \\
\hline No of individual & 393 & 153 & 75 & 621 \\
\hline Relative abundance & 63.29 & 24.64 & 12.08 & 100 \\
\hline Total no. of Species & 7 & 6 & 2 & 7 \\
\hline
\end{tabular}

intact forest followed by Erica woodland (Table 3; Fig. 5). Estimations of similarity indices between the five habitat types revealed that the intact forest and Erica woodland habitats were very similar in terms of species richness. Plantation forest has lowest species similarity with intact forest and Erica woodland (44\%). The pairwise comparisons of habitat diversity indices $\left(\mathrm{H}^{\prime}\right)$ using the diversity $t$ test showed significant difference between plantation forest and other habitat types except farmland $(p<0.05)$. Evenness was highest in the Erica woodland $(E=0.99)$ and the lowest in the disturbed forest $(E=0.73$ ) (Table 3). There was no statistically significant difference in rodent species diversity between seasons in all habitats $(P>0.05)$. Dominance was higher in the intact forest and Erica woodland where diversity was lowest.

Table 3. Diversity indices of rodent species in studied habitat types during wet and dry seasons

\begin{tabular}{|lllllllll|}
\hline Habitat & Season & No. of Species & Abundance & $\mathrm{H}^{\prime}$ & $\mathrm{Hmax}$ & $\mathrm{E}=\mathrm{H}^{\prime} / \mathrm{Hmax}$ & Dominance & $\mathrm{D}=1-\sum \mathrm{pi}^{2}$ \\
\hline Intact Forest & Dry & 2 & 66 & 0.67 & 0.70 & 0.96 & 0.52 & 0.48 \\
\hline \multirow{2}{*}{ Disturbed Forest } & Wet & 2 & 49 & 0.68 & 0.70 & 0.97 & 0.51 & 0.49 \\
& Dry & 3 & 57 & 0.89 & 1.10 & 0.81 & 0.46 & 0.54 \\
\hline \multirow{2}{*}{ Erica woodland } & Wet & 3 & 37 & 0.80 & 1.10 & 0.73 & 0.47 & 0.53 \\
& Dry & 2 & 40 & 0.67 & 0.70 & 0.96 & 0.52 & 0.48 \\
\hline \multirow{2}{*}{ Plantation Forest } & Wet & 2 & 35 & 0.69 & 0.70 & 0.99 & 0.50 & 0.50 \\
& Dry & 7 & 89 & 1.79 & 1.95 & 0.92 & 0.19 & 0.81 \\
\hline Farmland & Wet & 7 & 91 & 1.82 & 1.95 & 0.93 & 0.18 & 0.82 \\
\hline & Dry & 6 & 83 & 1.58 & 1.80 & 0.88 & 0.23 & 0.77 \\
\hline
\end{tabular}

$\mathrm{H}^{\prime}=$ Shannon-Weiner Index; Evenness= H'/Hmax; D=Diversity Index; Hmax=In(S)

Page 5/13 
The similarity index revealed that more species similarity was observed between intact forest and Erica woodland habitats (Table 4). However less similarity was recorded in plantation forest when crossed with intact forest and Erica woodland habitats. The overall similarity of species across all habitat types is very low (0.2).

Table 4. Similarity of rodent species among different habitat types during the study period

\begin{tabular}{|llllll|}
\hline Habitats & IF & DF & ERW & PF & FL \\
\hline IF & - & 0.8 & 1 & 0.44 & 0.5 \\
DF & 0.8 & - & 0.8 & 0.6 & 0.67 \\
\hline EWL & 1 & 0.8 & - & 0.44 & 0.5 \\
PF & 0.44 & 0.6 & 0.44 & - & 0.92 \\
FL & 0.5 & 0.67 & 0.5 & 0.92 & - \\
\hline
\end{tabular}

Similarity Index $(S I)=2 C / a+b+c+d+e+\ldots$

\section{Sex and age composition}

Out of the 621 individual rodents captured, adults comprised 260(41.9\%), sub-adults 248(39.9\%) and juveniles $113(18.2 \%)$. There was statistical difference between age groups $\left(X^{2}=64.38, \mathrm{df}=2, P<0.05\right)$. Adults were outnumbered subadults and juveniles in the study area. Out of the total trapped rodent species, the number of males 318(51.2\%) was slightly higher than females $303(48.8 \%)$ though the variation was not significant.

Table 5. Sex and age composition of trapped rodents during entire study period

\begin{tabular}{|llllll|}
\hline species & \multicolumn{3}{c}{ Sex } & \multicolumn{3}{c|}{ Age groups } \\
\cline { 2 - 6 } & M & F & Adult & subadult & Juvenile \\
\hline S. albicaudata & 93 & 86 & 70 & 69 & 40 \\
\hline S. albipes & 88 & 86 & 63 & 67 & 44 \\
\hline P. harringtoni & 48 & 51 & 46 & 44 & 9 \\
\hline L. flavopunctatus & 40 & 37 & 36 & 24 & 17 \\
\hline O. typus & 26 & 28 & 27 & 27 & 0 \\
\hline M. natalensis & 13 & 7 & 6 & 11 & 3 \\
\hline S.griseicauda & 10 & 8 & 12 & 6 & 0 \\
\hline Total & 318 & 303 & 260 & 248 & 113 \\
\hline Relative abundance (\%) & 51.2 & 48.8 & 41.9 & 39.9 & 18.2 \\
\hline
\end{tabular}

$M=m a l e, F=f e m a l e$

\section{Species Composition and Relative abundance of rodents trapped by Sherman live traps and Snap traps}

The relative abundance of live-trapped rodents varied from species to species with the highest capture (149) in the plantation forest and the lowest (70) in Erica woodland habitats during study period. From the snap trapped rodents the highest capture (31) was in plantation forest while the least (5) was in Erica woodland habitat. S. albicaudata was the highest captured species followed by $S$. albipes whereas $S$. griseicauda was the least trapped species in both Sherman live trap and snap trap captures. Highest trap success was recorded in the plantation forest (Sherman: 38.01, snap: 25.83) while the least was in the Erica woodland (Sherman: 17.86, snap: 4.17) during the study periods (Table 6).

Table 6. Comparison of rodent species composition, relative abundance and trap success of Sherman and snap trapping techniques from different habitat types 


\begin{tabular}{|c|c|c|c|c|c|c|c|c|c|c|c|c|c|c|}
\hline \multirow[t]{2}{*}{ Species } & \multicolumn{2}{|l|}{ IF } & \multicolumn{2}{|l|}{ DF } & \multicolumn{2}{|l|}{ EWL } & \multicolumn{2}{|l|}{$\mathrm{PF}$} & \multicolumn{2}{|l|}{$\mathrm{FL}$} & \multicolumn{2}{|l|}{ Total } & \multicolumn{2}{|l|}{ RA } \\
\hline & $\begin{array}{l}\text { Live } \\
\text { trap }\end{array}$ & $\begin{array}{l}\text { Snap } \\
\text { trap }\end{array}$ & $\begin{array}{l}\text { Live } \\
\text { trap }\end{array}$ & $\begin{array}{l}\text { Snap } \\
\text { trap }\end{array}$ & $\begin{array}{l}\text { Live } \\
\text { trap }\end{array}$ & $\begin{array}{l}\text { Snap } \\
\text { trap }\end{array}$ & $\begin{array}{l}\text { Live } \\
\text { trap }\end{array}$ & $\begin{array}{l}\text { Snap } \\
\text { trap }\end{array}$ & $\begin{array}{l}\text { Live } \\
\text { trap }\end{array}$ & $\begin{array}{l}\text { Snap } \\
\text { trap }\end{array}$ & $\begin{array}{l}\text { Live } \\
\text { trap }\end{array}$ & $\begin{array}{l}\text { Snap } \\
\text { trap }\end{array}$ & $\begin{array}{l}\text { Live } \\
\text { trap }\end{array}$ & $\begin{array}{l}\text { Snap } \\
\text { trap }\end{array}$ \\
\hline S. albicaudata & 38 & 9 & 31 & 5 & 39 & 2 & 20 & 5 & 23 & 7 & 151 & 28 & 28.5 & 30.76 \\
\hline S. albipes & 61 & 7 & 41 & 11 & 31 & 3 & 15 & 5 & 0 & 0 & 148 & 26 & 27.9 & 28.57 \\
\hline P. harringtoni & 0 & 0 & 3 & 3 & 0 & 0 & 46 & 6 & 34 & 7 & 83 & 16 & 15.6 & 17.58 \\
\hline $\begin{array}{l}\text { L. } \\
\text { flavopunctatus }\end{array}$ & 0 & 0 & 0 & 0 & 0 & 0 & 32 & 4 & 39 & 3 & 71 & 7 & 13.4 & 7.69 \\
\hline O. typus & 0 & 0 & 0 & 0 & 0 & 0 & 27 & 4 & 21 & 2 & 48 & 6 & 9.05 & 6.59 \\
\hline M. natalensis & 0 & 0 & 0 & 0 & 0 & 0 & 4 & 5 & 14 & 1 & 18 & 6 & 3.4 & 6.59 \\
\hline S. griseicauda & 0 & 0 & 0 & 0 & 0 & 0 & 5 & 2 & 6 & 0 & 11 & 2 & 2.07 & 2.19 \\
\hline Total & 99 & 16 & 75 & 19 & 70 & 5 & 149 & 31 & 137 & 20 & 530 & 91 & 100 & 100 \\
\hline Trap nights & 392 & 120 & 392 & 120 & 392 & 120 & 392 & 120 & 392 & 120 & 1960 & 600 & & \\
\hline Trap success & 25.26 & 13.33 & 19.13 & 15.83 & 17.86 & 4.17 & 38.01 & 25.83 & 34.95 & 16.67 & 27.04 & 15.17 & & \\
\hline
\end{tabular}

Designations: IF= Intact forest, $\mathrm{DF}=$ Disturbed forest, $\mathrm{EWL}=$ Erica Woodland, $\mathrm{PF}=$ Plantation Forest, $\mathrm{FL}=$ Farmland, $\mathrm{RA}=$ relative abundance $(\%)$.

Table 7. Comparison of the number of species trapped and number of habitat types surveyed with other studies.

\begin{tabular}{|llll|}
\hline Study site & Source & Number of rodent species & No. of habitat types \\
\hline Southeast Ivory Coast & {$[32]$} & 13 & 3 \\
\hline Alage, Southern Ethiopia & {$[35]$} & 11 & 4 \\
\hline Mayuge district, Eastern Uganda & {$[36]$} & 11 & 4 \\
\hline Wondo Genet, Ethiopia & {$[29]$} & 7 & 5 \\
\hline Chebera Churchura National Park, Ethiopia & {$[12]$} & 15 & 7 \\
\hline Aridtsy forest, Awi, Ethiopia & {$[33]$} & 7 & 4 \\
\hline Yetere Forest, Ethiopia & {$[37]$} & 5 & 4 \\
\hline Klte-Awla'elo District, Tigray, Ethiopia & {$[30]$} & 6 & 4 \\
\hline Alto Beni, Bolivia & {$[38]$} & 10 & 4 \\
\hline Aquatimo forest, East Gojjam, Ethiopia & {$[34]$} & 8 & 5 \\
\hline Wof Washa Natural State Forest, Ethiopia & This study & 7 & 4 \\
\hline
\end{tabular}

\section{Discussion}

Although WWNSF is deemed to encompass iconic species of small mammals endemic to the country, no study has been conducted yet regarding species composition, abundance and population of rodents in the area. Accordingly, this study presents the first inventory of rodent species in WWNSF, Ethiopia. The current findings of the study have been compared with studies conducted elsewhere in the country as there was no longitudinal data documented concerning rodent species of this study area.

Seven species of rodents were identified during this study. The number of species recorded in this study was much lower in contrast to several studies in other localities in Ethiopia and other regions in Africa which possibly a reflection of either lower rodent diversity or lower trap chance in catching more species of rodents including other small mammals [12,32] (Table 7). Indeed, the lower number of rodent species in this study might also be attributed to the seasonal factors of the trap period or the intensiveness of trap survey duration. Moreover, other studies reported equivalent data though there is variation in the number of habitat types surveyed which possible yield variance $[29,30,33,34]$.

Out of the seven species recorded in the area, S. albicuadata (28.82) and S. albipes (28.02) were the most abundant. Most species were trapped from modified habitats (plantation and farmland habitats) whereas least number of species were recorded from natural intact and disturbed forest, and Erica woodland. Among seven species of rodents trapped, S. albicaudata was found in all habitats while $S$. albipes trapped from four 
habitats followed by $P$. harringtoni trapped from three habitat types. Other four species were distributed in two habitats with lower abundance. $M$. natalensis (3.22) and S. griseicauda (2.9) were the least abundant species trapped from plantation and farmland habitats. This is contrary to the view point that $M$. natalensis have been considered as the most adaptable and widespread species of rodent in Ethiopia [7, 12, 33, 37]. However, the finding confines to the report that stated $M$. natalensis as a common species in crop fields including human environment than in natural vegetation $[7,39]$.

In this study, trapping success varied among habitat types and between seasons. The highest mean trap success was recorded from the plantation forest (35.2\%) and farmland habitat of (30.7\%) during both seasons while Erica woodland habitat (14.65\%) was with the least mean trap success. This might be associated with low predation risk and food availability in plantation and farmland habitats. Moreover, the topographical location of Erica woodland habitat might pose climatic stress on rodent species affecting their activity patterns as this habitat is at a higher elevation. The overall mean trap success (24.26\%) of the present study area was higher as compared with studies from Arbaminch Forest and Farmlands (17.6\%) [39], Menagesha-Suba State Forest (9.1\%) [31], Aquatimo forest, East Gojjam (13.6\%) [34], Bumdeling Ramsar Site, Trashiyangtse, Eastern Bhutan (11.03\%) [40], Wondogent (12.7\%) [29] and Yetere Forest, Gishe Rabel, Ethiopia (13.74\%) [37]. This might possibly associated with factors like Climatic factors, vegetation types, changes in the availability of food, cover and activity of animals which have dropping effect on trap success [12, 31, 37].

In the present study, more species diversity of rodents was recorded during wet season compared to the dry season in all habitats except disturbed forest. The highest value of Shannon-Wiener index $\left(H^{\prime}\right)$ was recorded in plantation forest $\left(H^{\prime}=1.82\right)$ followed by farmland habitat $\left(H^{\prime}\right.$ $=1.67)$ during the wet season and the lowest value was observed in the intact natural forest $\left(H^{\prime}=0.67\right)$ and Erica woodland $\left(H^{\prime}=0.67\right)$ during the dry season. This is contrary to reports that stated the presence of more rodent species diversity in the natural habitats than in modified habitats (plantation and farmland) [39]. However, this finding supports reports that presented highest number of species from farmland habitat than the natural habitats $[33,34]$. The higher number of rodents in the plantation and farmland habitat might be associated with availability of diversified food sources and lower abundance of predators as compared with natural forest habitats. Estimations of similarity indices between the five habitat types revealed that the intact forest and Erica woodland habitats were very similar in terms of species richness. However, plantation forest showed lowest species similarity with intact forest and Erica woodland (44\%).

Out of the 621 individual rodents captured, adults comprised $260(41.9 \%)$, sub-adults $248(39.9 \%)$ and juveniles $113(18.2 \%)$. There was statistical difference between age groups $\left(X^{2}=64.38, \mathrm{df}=2, P<0.05\right)$. Adults were outnumbered subadults and juveniles in the study area. This is in line with other study that stated domination of rodent population structure by adult individuals [35]. The possible reason for high abundance of male rodent in a population might be high mobility behavior of males and low mobility of females due to reproduction and parental care engagement. Although the difference was not significant, the number of males $318(51.2 \%)$ was slightly higher than females $303(48.8 \%)$ though the variation was not significant. Opposite finding was reported by [39] where females comprised 319 (51.4\%) and males 301 (48.6\%).

The relative abundance of both live-trapped and snap trapped rodents varied from species to species with the highest capture (Sherman: 149, snap: 31) in the plantation forest and the lowest (Sherman: 70, snap: 5) in Erica woodland habitats during study period. This shows that there was no variation in the abundance ranking of rodent species trapped in the area with reference to the trapping technique type. This finding is contrary to the report that showed a reverse abundance ranking of $S$. albipes and L. flavopunctatus based on the trapping tools used [29]. This might be associated to the variation in the time of data collection, habitat cover, the bait used the two studies, physiological situation of the animals and human disturbance level in the two studies.

In conclusion, the present study provides the first valuable demonstration on the species composition, relative abundance and distribution of rodents in the WWNSF. Out of the total rodents caught in the study period, Stenocephalemys albipes, Pelomys harringtoni and Lophuromys flavopunctatus are endemics to Ethiopia.

The following points are recommended to enhance the conservation value of Rodents.

- Although, the research result confirmed the presence of seven rodent species in the study area, it provides a window on the need of further, more extensive sampling with the incorporation of additional trap sites to the lower altitude for further monitoring and inventory of small mammals to document the different endemic and endangered rodent species.

- The forest area has not been clearly demarcated. Accordingly, there should be demarcation to hinder agricultural expansion into the forest area which provide travel corridor to villages for pest rodents that cause yield damage.

\section{Abbreviations}

DF: Disturbed forest; EWL: Erica Woodland; FL: Farmland; IF: Intact forest; PF: Plantation Forest; RA: relative abundance; WWNSF: Wof Washa Natural State Forest. 


\section{Declarations}

Ethics approval and consent to participate

Permits for this research were issued by the Ethiopian Wildlife Conservation

Authority (EWCA), Tarmaber District Rural Development and Agriculture Office and WWNSF forest management office.

Consent for publication

This manuscript does not contain any individual person's data, and further consent for publication is not required/ applicable.

\section{Competing interests}

The authors declare that they have no competing interests with respect to the research, authorship and/or publication of this article.

Funding

Ethiopian Ministry of Education offered the fund to MN in such a way that she deployed it for data collection purpose regarding species composition, relative abundance and distribution of rodents in Wof-Washa Natural State Forest. Debre Berhan University also facilitated the logistic during data collection.

\section{Authors Contributions}

MN collected, analyzed the data and was a major contributor in writing the draft manuscript. DY organized the manuscript and checked the data collected and analyzed for final submission. GD and GG revised both the draft manuscript and the final version. All authors read and approved the final manuscript.

\section{Acknowledgements}

We would like to thank Mr. Solomon Mengistu and Mr. Ketema Amberbir for their assistances to MN during rodent species identification in the Zoological National History Museum, Addis Ababa University.

\section{Availability of data and materials}

The data used to support the findings of this study are available from the corresponding author request.

\section{References}

1. Yalden D, Largen M: The endemic mammals of Ethiopia. Mammal Review 1992, 22(3-4):115-150.

2. Alemayehu E: Distribution of small mammals and human induced factors in Gulme forest patches (Birsheleko), West Gojjam, Ethiopia. Asian Journal of Conservation Biology 2014, 3(2):170-174.

3. Yazezew D, Bekele A, Ibrahim H: Activity Budget and Feeding Ecology of Geladas (Theropithecus gelada obscurus) around Abogedam Church West of Debre Berhan Town, Ethiopia. The Scientific World Journal 2020, 2020:10.

4. Avenant L, Cavallini P: Correlating rodent community structure with ecological integrity, Tussen-die-Riviere Nature Reserve, Free State Province, South. Integrated Zoology 2007, 2:212-219.

5. Davies G: African Forest Biodiversity: A field Survey Manual for Vertebrates. Cambridge: Earthwatch; 2002.

6. Assogbadjo AE, Codjia JTC, Sinsin B, Ekue MRM, Mensah GA: Importance of rodents as a human food source in Benin. Belgian Journal of Zoology 2005, 135:11-15.

7. Habtamu T, Bekele A: Habitat association of insectivores and rodents of Alatish National Park, northwestern Ethiopia. Trop Ecol 2008, 49(1):1-11.

8. Capelli JL: Landscape Ecology of Rodents in a No-Till Agriculture System. Washington D.C.: Washington State Uiversity; 2005.

9. Avenant L: The potential utility of rodents and other small mammals as indicators of ecosystem 'integrity' of South African grasslands. Wildlife Resources 2011, 38:626-639.

10. Gorbunova V, Bozzella MJ, Seluanov A: Rodents for comparative aging studies: from mice to beavers. AGE 2008, 30:111-119.

11. Admas A, Yihune M: Species composition, relative abundance and habitat association of rodents in Yekoche Forest, East Gojjam, Ethiopia. Int J Biodivers Conserv 2016, 8(9):216-223.

12. Datiko D, Bekele A: Habitat association and distribution of rodents and insectivores in Chebera Churchura National Park, Ethiopia. Trop Ecol 2014, 55(2):221-229. 
13. Assefa A, Chelmala S: Comparison of rodent community between natural and modified habitats in KaftaSheraro National Park and its adjoining villages, Ethiopia: implication for conservation. The Journal of Basic and Applied Zoology $2019,80$.

14. Osie M, Bekele A, Balakrishnan M: An ecological study on rodents of natural vegetation and farm lands in Siltie, Central Ethiopia. SINET: Ethio J Sci 2010, 33(1):59-66.

15. Bekele A, Leirs H: Population ecology of rodents of maize fields and grassland in central Ethiopia. Belgian Journal of Zoology 1997, 127:3948.

16. Fitzherbert E, Gardner T, Caro T, Jenkins P: Habitat preferences of small mammals in the Katavi ecosystem of western Tanzania. African Journal of Ecology 2007, 45:249-257.

17. Wilson D, Reender D: Mammal species of the world: A Taxonomic and Geographic Reference vol. 1, 3 edn. Maryland: Johns Hopkins University Press; 2005

18. Wolff JO, Sherman PW: Rodent Societies as Model Systems. In: Rodent :Societies An Ecological and Evolutionary Perspective. Edited by Wolff JO, Sherman PW. Chicago: University of Chicago Press; 2007: 3-7.

19. Mengistu S, Bekele A: Geographic variation in the Ethiopian common Molerat (Tachyorycte ssp lendens) based on morphometry Ethiopian Journal of Biological Sciences 2003, 2:73-89.

20. Lavrenchenko LA, Bekele A: Diversity and conservation of Ethiopian mammals: what have we leamed in 30 years? Ethiopian Journal of Biological Sciences 2017, 16:1-20.

21. Datiko D, Bekele A: Species composition and abundance of small mammals in Chebera-Churchura National Park, Ethiopia. Journal of Ecology and the Natural Environment 2013, 5(6):95-102.

22. Yihune M, Bekele A: Diversity, distribution and abundance of rodent community in Afro-alpine Habitat of the Semien Mountain National Park, Ethiopia. International Journal of Zoological Research 2012, 8(4):137-149.

23. Bekele T: Vegetation Ecology of Renunant Afromontane Forests on the Central Plateau of Shewa, Ethiopia Uppssala, Sewden: Uppsala University; 1993.

24. Friis I, Sebsebe Demissew, Van Bruegel P: Atlas of the Potential Vegetation of Ethiopia. Addis Ababa: Addis Ababa University Press and Shama Books; 2011.

25. Teketay D, Bekele T: Floristic composition of Wof-Washa natural forest, Central Ethiopia: Implications for the conservation of biodiversity Feddes Repertorium 1995, 106:127-147.

26. Tilahun A: Vegetation Ecology and Carbon Stock of Wof-Washa Forest, North Shewa Zone, Amhara Region, Ethiopia. PhD. Addis Ababa: Addis Ababa University; 2018.

27. Fisaha G, Hundera K, Dalle G: Woody plants' diversity, structural analysis and regeneration status of Wof Washa natural forest, North-east Ethiopia. African Journal of Ecology 2013, 51(4):599-608.

28. Linzey A, Kesner M: Small mammals of a woodland savannah ecosystem in Zimbabwe.l. Density and habitat occupancy patterns. Journal of Zoology of London 1997, 243:137-152.

29. Kassa D, Bekele A: Species composition, abundance, distribution and habitat association of rodents of Wondo Genet, Ethiopia. SINET: Ethio J Sci 2008, 31(2):141-146.

30. Welegerima K, Meheretu Y, HAILESELASSIE T, GEBRE B, KIDANE D, MASSAWE A, MBIJE N, MAKUNDI R: Abundance and microhabitat use of rodent species in crop felds and bushland in Ethiopia. Journal of Vertebrate Biology 2020, 69(2):20054.

31. Bekele A: Population dynamics of Ethiopian endemic rodents,Praomys albibes in the Menagesha State Forest. Journal of Zoology of London 1996, 238:1-12.

32. Ahissa L, Akpatou B, Bohoussou H, Kadjo B, Koné I: Species composition and community structure of terrestrial small mammals in Tanoé ehy swamp forest (southeast Ivory Coast): Implication for conservation. Nature Conservation Research 2020, 5(1):53-63.

33. Bantihun G, Bekele A: Diversity and habitat association of small mammals in Aridtsy forest, Awi Zone, Ethiopia. Zoological Research 2015, 36(2): 88-94.

34. Dubale M, Ejigu D: Diversity, relative abundance and habitat association of rodents in aquatimo forest patches and adjacent farmland, east Gojjam, Ethiopia. Ethiopian Journal of Biological Sciences 2015, 14(2):201-216.

35. Addisu A, Bekele A: Population structure of rodents in Alage, Southern Ethiopia. Journal of Ecology and the Natural Environment 2015, 7(1):7-13

36. Mayamba A, Byamungu R, Makundi R, Kimaro D, Isabirye M, Massawe A, Kifumba D, ..., Mulungu L: Species composition and community structure of small pest rodents (Muridae) in cultivated and fallow fields in maize-growing areas in Mayuge district, Eastern Uganda. Ecol Evol 2019, 9:7849-7860.

37. Getachew G, Balakrishnan M, Bekele A: Species Composition and Habitat Association of Rodents in Yetere Forest, Central Ethiopia. nternational Journal of Ecology and Environmental Sciences 2016, 42(3):193-200. 
38. Revollo-Cadima S, Rico CA, Pacheco L, Salazar-Bravo J: Community structure and abundance of small rodents at the wave front of agroforestry and forest in Alto Beni, Bolivia. Ecología en Bolivia 2020, 55(1):16-25.

39. Datiko D, Bekele A, Belay G: Species composition, distribution and habitat association of rodents from Arbaminch forest and farmlands, Ethiopia. African Journal of Ecology 2007, 45:651-657.

40. Norbu L, Thinley P, Phurpa, Dechen U, Tshering P: Diversity and seasonal abundance of small mammals in Bumdeling Ramsar Site, Trashiyangtse, Eastern Bhutan. Journal of Biodiversity and Environmental Sciences 2020, 15(3):36-45.

\section{Figures}

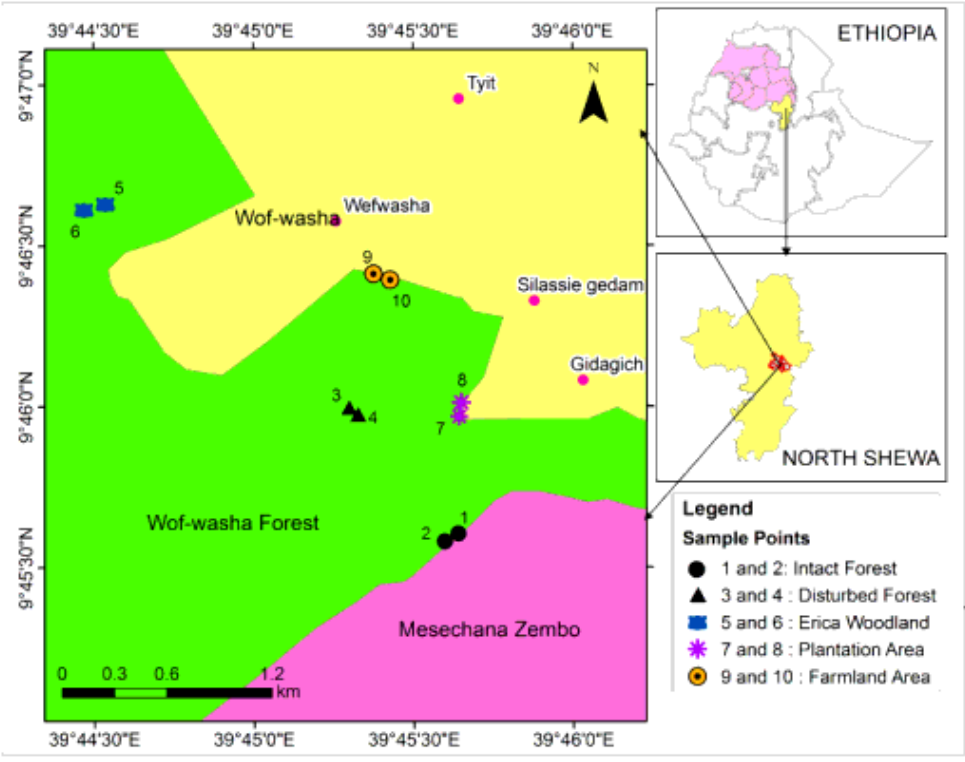

\section{Figure 1}

Map of the study area and location of sampling area. Note: The designations employed and the presentation of the material on this map do not imply the expression of any opinion whatsoever on the part of Research Square concerning the legal status of any country, territory, city or area or of its authorities, or concerning the delimitation of its frontiers or boundaries. This map has been provided by the authors.

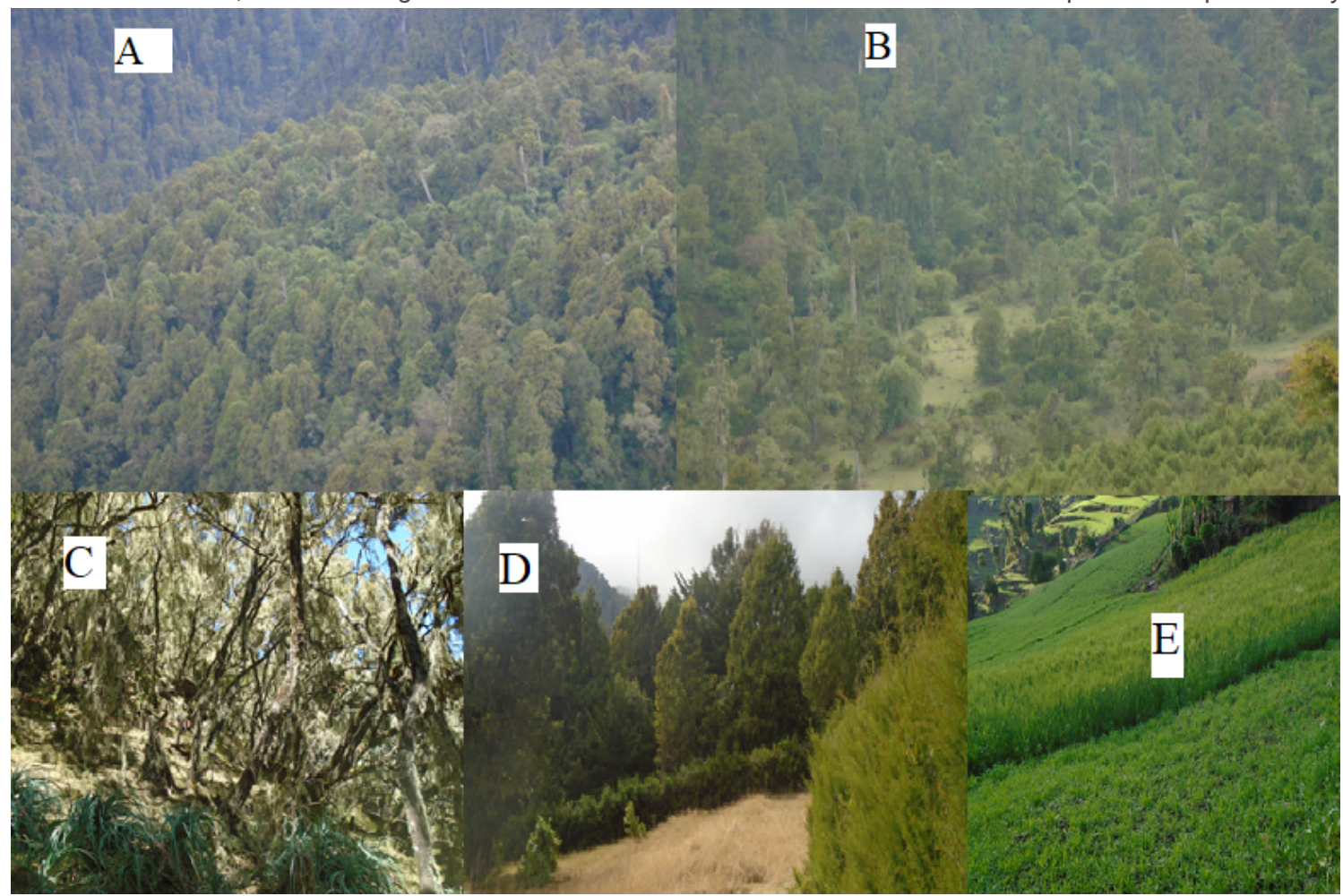


Figure 2

Habitat types of sample grids: Intact forest (A), Disturbed forest (B), Erica woodland (C), Plantation forest (D) and Farmland (E) habitats.

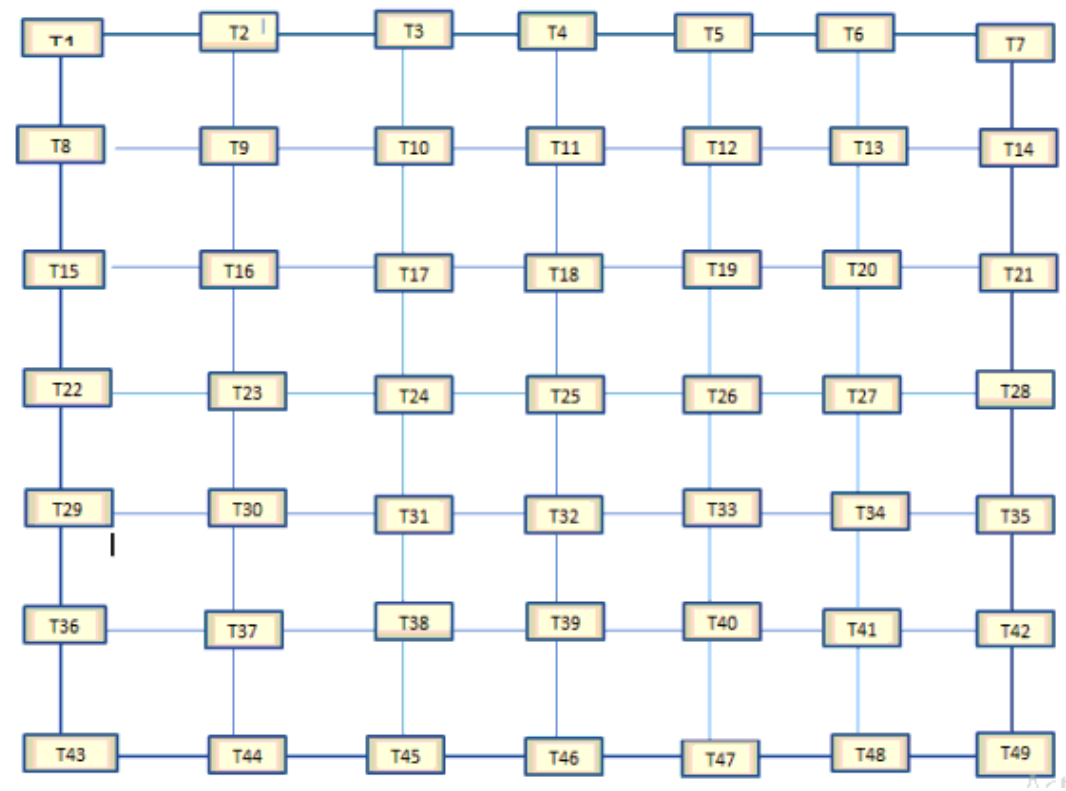

Figure 3

Diagrammatic representation of Sherman live trappings grid length were recorded for identification purpose.

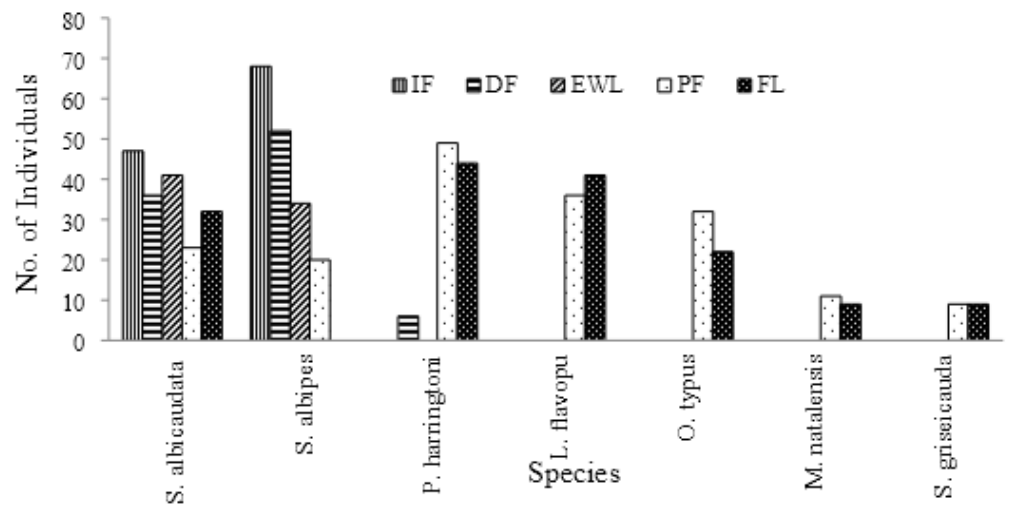

Figure 4

Abundance and distribution of rodent species in five different habitat types of WWNSF (IF: Intact Forest, DF: Disturbed Forest, EWL: Erica Woodland, PF: Plantation Forest, FL: Farmland) 

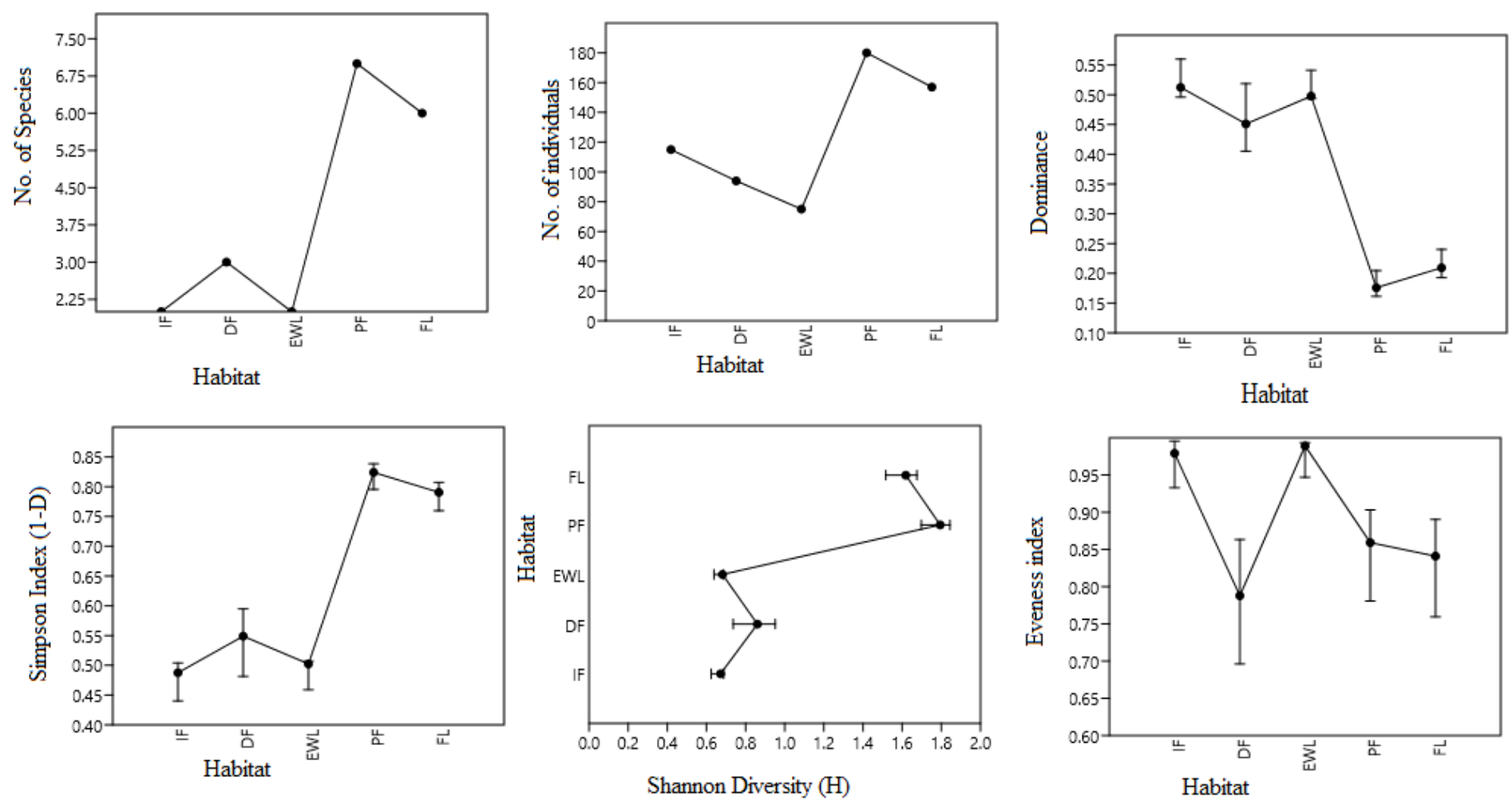

Figure 5

Diversity indices of rodent species at WWNSF (IF: Intact Forest, DF: Disturbed Forest, EWL: Erica Woodland, PF: Plantation Forest, FL: Farmland). 